\title{
Tocilizumab in the treatment of rheumatoid arthritis and beyond
}

This article was published in the following Dove Press journal:

Drug Design, Development and Therapy

28 March 2014

Number of times this article has been viewed

\author{
Anjali Shetty' \\ Rebekah Hanson' \\ Peter Korsten ${ }^{2}$ \\ Munir Shawagfeh ${ }^{3}$ \\ Shiva Arami' \\ Suncica Volkov' \\ Olga Vila' \\ William Swedler' \\ Abdel Naser Shunaigat ${ }^{4}$ \\ Sameer Smadi ${ }^{4}$ \\ Ray Sawaqed 5 \\ David Perkins' \\ Shiva Shahrara' \\ Nadera J Sweiss' \\ 'Department of Rheumatology, \\ Pharmacy, Transplant, University of \\ Illinois at Chicago, Chicago, IL, USA; \\ ${ }^{2}$ Department of Nephrology and \\ Rheumatology, University Medicine \\ Göttingen, Göttingen, Germany; \\ ${ }^{3}$ Anesthesia and Pain Management, \\ King Hussein Cancer Center, Amman, \\ Jordan; ${ }^{4}$ Liver Transplant, Kidney \\ Transplant Royal Medical Services, \\ Jordan; ${ }^{5}$ Cardiac Surgery Methodist \\ Hospitals, Merrillville, IN, USA
}

Correspondence: Nadera J Sweiss I80I W Taylor, Suite 3C, Chicago, IL, USA 606I2

Email: nsweiss@uic.edu
Abstract: Rheumatoid arthritis (RA) is a systemic inflammatory disease characterized by joint pain, swelling, stiffness, and progressive destruction of the small joints of the hands and feet. Treatment of RA has improved over the past decade. With multiple cytokines well-known now to play a role in the pathogenesis of RA, including tumor necrosis factor alpha, interleukin (IL)-1 $\beta$, and IL-6, many targeted biological treatments against these cytokines have emerged, changing the treatment of this disease. Tocilizumab (TCZ) is a recombinant humanized monoclonal antibody against the IL-6 receptor and has been approved in many countries, including the United States, for the treatment of moderate to severe RA in patients who have not adequately responded to one or more disease-modifying antirheumatic drugs (DMARDs) or cannot tolerate other approved drug classes for RA. The aim of this review is to discuss the role of IL-6 in RA, and to provide an overview of the mode of action, pharmacokinetics, and safety of TCZ. Furthermore, efficacy studies of TCZ as both monotherapy and combination therapy will be evaluated. There have been several important clinical trials evaluating the efficacy and safety of TCZ in RA patients; this review summarizes this data from 14 key trials with emphasis on Phase III trials. Review of these trials provides strong evidence that its use, both as monotherapy and in combination with methotrexate or other DMARDs, is an effective treatment in reducing the signs and symptoms of RA. TCZ showed tolerable safety but care is required for its use since there are some important safety concerns including elevated liver enzymes, elevated low-density lipoprotein, infections, and gastrointestinal perforations. Additionally, given the efficacy of TCZ in the treatment of RA, this review discusses how TCZ may be beneficial in the treatment of other autoimmune diseases, spinal disease, cardiovascular disease, organ transplantation, and malignancies where elevated levels of IL-6 may play a role in the pathogenesis of these diseases.

Keywords: tocilizumab, IL-6, rheumatoid arthritis, biologics

\section{Introduction}

Rheumatoid arthritis (RA) is a chronic systemic inflammatory autoimmune disease causing a symmetrical polyarthritis characterized by persistent synovitis and destruction of bone and cartilage in multiple joints. RA affects about $1 \%$ of adults aged $>35$ years and $>2 \%$ of adults aged $>60$ years and is more common in women. ${ }^{1}$ The etiology of RA is thought to be multifactorial and is not fully understood; however, proinflammatory cytokines are known to play a role in the disease pathogenesis in RA by propagating inflammation and leading to joint destruction. ${ }^{2}$ These key cytokines include tumor necrosis factor alpha (TNF- $\alpha$ ), interleukin (IL)-1 $\beta$, and IL-6. ${ }^{3}$ First-line drug therapies that are US Food and Drug Administration (FDA)-approved for the treatment of RA include conventional disease-modifying antirheumatic drugs (DMARDs) 
including hydroxychloroquine, methotrexate (MTX), sulfasalazine, and leflunomide. Gold agents, cyclosporine, and azathioprine are now rarely used. Nonsteroidal antiinflammatory medications as well as corticosteroids are generally used in conjunction with DMARDs as adjunctive therapy. For patients with an insufficient response to these conventional agents, a combination of DMARDs or biological agents may be indicated. Biologics include the TNF- $\alpha$ inhibitors etanercept, adalimumab, infliximab, golimumab, and certolizumab; the IL-1 inhibitor anakinra; the selective modulator of $\mathrm{T}$ cell activation, abatacept; and rituximab, a $\mathrm{B}$ cell depleting monoclonal antibody directed against the CD20 antigen. ${ }^{4}$ All of these agents have been successfully used in the treatment of RA, but are not always effective. Of all the biologics listed, anti-TNF- $\alpha$ agents were the first biologics studied and approved. ${ }^{5}$ TNF- $\alpha$ inhibitors have been established as an effective treatment option for RA, especially in patients who experience an inadequate response to the conventional DMARDs listed above, including MTX. There is no direct comparison data between the five currently approved TNF- $\alpha$ inhibitors; however, meta-analyses of clinical trial data suggest these compounds have similar efficacy. ${ }^{6}$ They differ in terms of molecular structures and route of application (subcutaneous versus intravenous). A significant portion of patients have an inadequate response $(20 \%-40 \%)$ to anti-TNF- $\alpha$ agents with regards to clinical signs and symptoms. ${ }^{7}$ The many patients who do not respond to the conventional DMARDs, biologics, or are unable to take these medications secondary to problems with adverse effects create a demand for new therapies in the treatment of RA.

Tocilizumab (TCZ), a new drug targeting the IL-6 pathway, was approved in 2010 for the treatment of moderate to severe RA in patients who have failed other DMARDs, including biologics. It is the first humanized IL-6 receptor-inhibiting monoclonal antibody. ${ }^{8} \mathrm{IL}-6$ is a $26 \mathrm{kDa}$ glycopeptide. This cytokine plays a role in inflammation, bone metabolism, hematopoiesis, and immune regulation. IL-6 is produced by various cell types, predominantly macrophages and fibroblasts. ${ }^{9}$ IL- 6 is known to be produced in high quantities in the synovial fluid of patients with RA and these elevations correlate with disease activity and joint destruction. ${ }^{10}$

The purpose of this paper is to review the role of TCZ in the treatment of RA, focusing on the pharmacology, efficacy, and safety of this drug as demonstrated by important clinical trials. Lastly, we will address the evolving role of TCZ in the future.

\section{Pathogenesis of RA and the role of IL-6}

The pathogenesis of RA is highly complex and involves interconnected cellular and molecular pathways involving B cells, T cells, and cytokines, ultimately causing articular inflammation resulting in joint destruction. Antibodies directed against joint-specific and systemic autoantigens are commonly detected in the blood of RA patients and are thought to contribute to the local inflammation. The concept that autoantibodies, such as rheumatoid factor and anti-cyclic citrullinated peptide, are pathogenic fostered the development of targeted B cell depletion in RA with rituximab. T cells have also been implicated in RA due to their presence in the synovium. Subsets of T cells have been defined that produce cytokines in the rheumatoid synovium including $\mathrm{T}$ helper 17 cells that also play a role in neutrophil migration. Another subset, regulatory $\mathrm{T}$ cells can cause immune suppression, which all contributes to pannus formation in RA. Abatacept, a biologic agent that blocks $\mathrm{T}$ cell costimulation, targets $\mathrm{T}$ cells to treat RA.

Macrophages and fibroblasts are the primary sources of cytokines in the synovium of RA patients. Synovial macrophages and fibroblasts produce a multitude of proinflammatory factors in the rheumatoid joint including IL-1 $\beta$, IL-6, IL-17, and TNF- $\alpha .{ }^{11}$ These cytokines enhance and propagate synovial inflammation. IL-6 has an assortment of effects on the immune system including stimulating fibroblasts, osteoclasts, macrophages, production of helper $\mathrm{T}$ cells and regulatory $\mathrm{T}$ cells, playing a role in $\mathrm{B}$ cell activation and differentiation, and inducing the production of C-reactive protein. IL-6 is a major cytokine inducer of acute phase response proteins, and it is known to be an endogenous pyrogen, therefore playing a role in the systemic and constitutional manifestations of RA.

IL-6 acts upon neutrophils, which are cells that play an important role in the acute inflammatory response in the synovium of RA patients. IL-6 increases neutrophil adherence to fibroblasts, which, as a result, leads to leukocyte recruitment causing inflammation. ${ }^{12}$ Since IL-6 can stimulate osteoclast maturation and activation via RANKL (receptor activator of nuclear factor kappa-B ligand) as well as synovial proliferation, it can contribute to the synovial pannus formation seen in RA. IL-6 acts synergistically with IL- $1 \beta$ and TNF- $\alpha$ to promote angiogenesis as a result of increased production of vascular endothelial growth factor (VEGF). ${ }^{13}$ This IL-6 stimulated increase in VEGF is important for pannus formation. IL-6 may also contribute to $\mathrm{T}$ helper 17 cell differentiation, which 
in turn leads to the production of more cytokines by macrophages including IL- $1 \beta$ and TNF- $\alpha$.

IL-6 works through two differing signaling pathways, a membrane bound IL- 6 receptor and a soluble IL- 6 receptor. Normally, the IL-6 receptor binds to IL-6 and to a cell-surface glycoprotein called gp130, which is necessary for signal transduction. The gp130-mediated IL-6 signaling pathway works even for cells that do not express the membrane bound IL-6 receptor on their surface. IL- 6 and the soluble IL- 6 receptor are present in serum and synovial fluids and are seen in higher levels in patients with RA. ${ }^{14}$ All of these functions in which IL-6 mediates the systemic and articular features of RA make IL-6 blockade an attractive biologic target therapy for the treatment of RA (Figure 1). ${ }^{9}$

\section{Pharmacokinetics and metabolism}

TCZ is a humanized IgG1 monoclonal antibody that binds with high affinity to both the soluble and membranebound forms of the IL- 6 receptor, which prevents IL- 6 from binding to its receptor. It is developed by grafting the complementarity determining regions of a mouse antihuman IL-6 receptor antibody onto human IgG1.${ }^{15} \mathrm{TCZ}$ has a nonlinear pharmacokinetic profile. The maximum concentration increases in approximate proportion to increases in dosage, whereas the area under the concentration-time curve increases disproportionately. As the dosage increases, clearance and the apparent elimination rate constantly decrease, and terminal half-life and mean residence times are prolonged. ${ }^{16}$

TCZ binds to soluble IL-6 receptor in a dose-dependent manner and saturates the receptor at approximately $0.1 \mu \mathrm{g} / \mathrm{mL}$. TCZ also competitively inhibits IL-6 binding to soluble IL-6 receptor and complete inhibition is seen at approximately $4 \mu \mathrm{g} / \mathrm{mL}$. The elimination of TCZ is biphasic, vacillating between nonlinear and linear clearance pathways, and is highly dependent on serum drug concentration. ${ }^{12}$ At low serum concentrations, the non-linear pathway is predominant and is specifically associated with the degree of saturation of the IL-6 receptor. ${ }^{17}$ Once target saturation occurs, a more nonspecific linear clearance pathway dominates; the linear

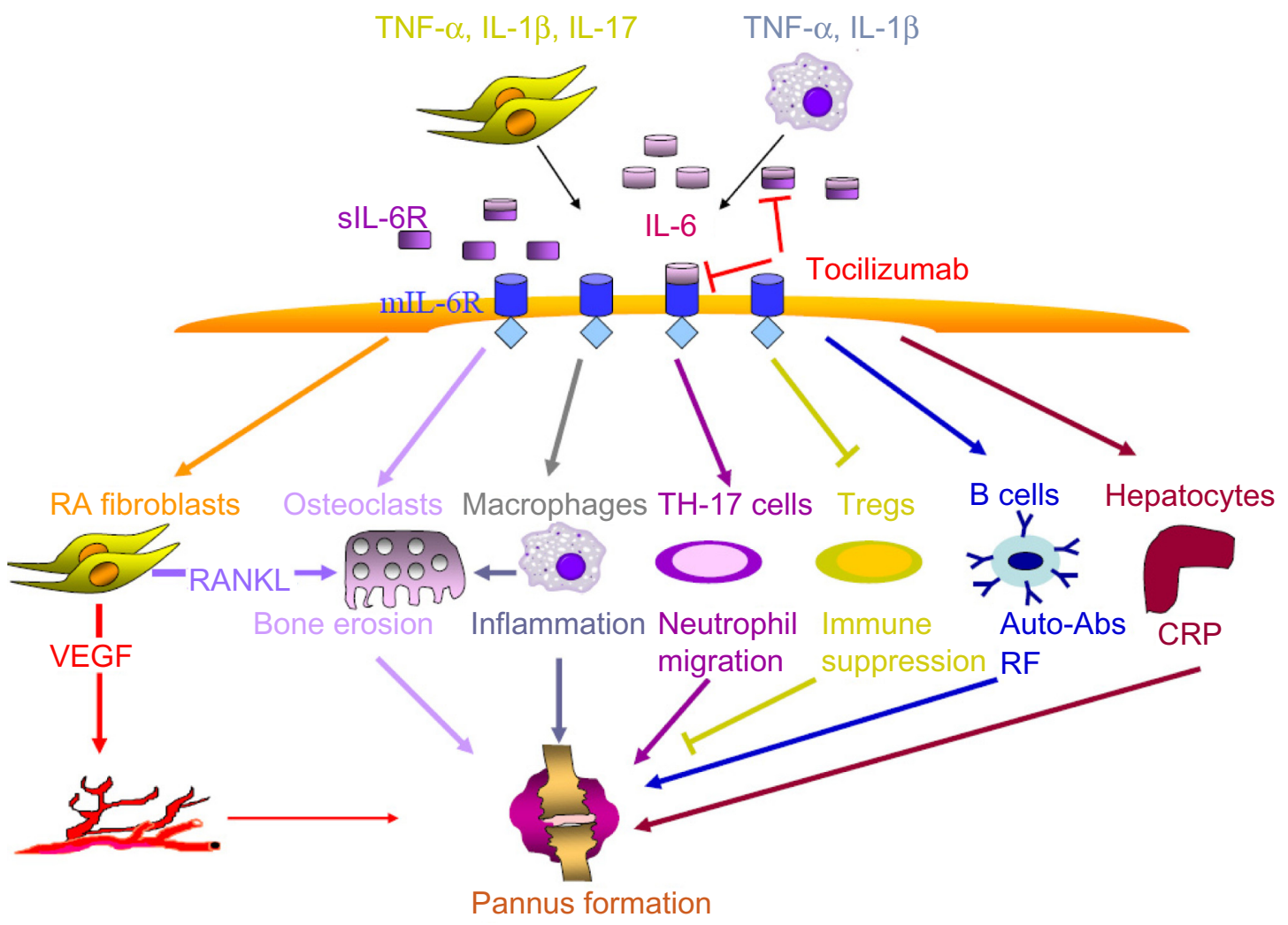

Figure I Functions of IL-6 in RA and blockage of IL-6 signal transduction by tocilizumab.

Notes: Macrophages and fibroblasts produce IL-6, in addition to other proinflammatory cytokines including TNF- $\alpha$, IL-I $\beta$, and IL-I7. IL-6 is a pleiotropic proinflammatory cytokine with a variety of biologic effects regulating angiogenesis, bone metabolism, inflammation, immune suppression, autoantibody production, and production of CRP, which all contribute to the pannus formation seen in RA. Tocilizumab blocks these effects by binding to both the soluble and membrane-bound forms of the IL-6 receptor. Abbreviations: Auto-Abs, autoantibodies; CRP, C-reactive protein; IL, interleukin; mIL-6R, membrane bound IL6-receptor; RA, rheumatoid arthritis; RANKL, receptor activator of nuclear factor kappa-B ligand; RF, rheumatoid factor; sIL-6R, soluble IL-6 receptor; TH-I7, T helper I7; TNF- $\alpha$, tumor necrosis factor alpha; Tregs, regulatory T cells; VEGF, vascular endothelial growth factor. 
clearance continues to proportionally increase with body weight exceeding $100 \mathrm{~kg}$, which may result in unnecessarily high drug exposure. Therefore, doses exceeding $800 \mathrm{mg}$ per infusion are not recommended. ${ }^{18}$ Additionally, more sustained target saturation occurs with infused doses of $8 \mathrm{mg} / \mathrm{kg}$ every 4 weeks compared to $4 \mathrm{mg} / \mathrm{kg}$, resulting in reduced elimination and a longer half-life with higher serum concentrations. This prolonged exposure with the highest dose may also be associated with improved response. ${ }^{19}$

Alcohol, age, and race have not been found to affect the pharmacokinetics of TCZ. ${ }^{20}$ So far, there are no studies addressing the effect of hepatic or renal impairment on the pharmacokinetics of TCZ. There does not appear to be a need to adjust the dose for mild renal impairment. ${ }^{18}$ In the United States, TCZ was approved in early 2010 for the treatment of adult patients with moderate to severe RA of which response to anti-TNF therapies was inadequate. Its indication was later expanded to include inadequate response to one or more DMARDs. ${ }^{15}$ In Europe, TCZ is approved in combination with MTX for the treatment of moderate to severe RA in adults who have not responded to or did not tolerate previous DMARD or anti-TNF therapies. ${ }^{21}$ It can be used as monotherapy if MTX is not appropriate. The European League Against Rheumatism (EULAR) recommends use of TCZ in combination with MTX as a second-line therapy to conventional DMARDs. ${ }^{22}$ The recommended dose of TCZ is $4 \mathrm{mg} / \mathrm{kg}$, with an increase to $8 \mathrm{mg} / \mathrm{kg}$, based on response, given every 4 weeks as an intravenous infusion over 1 hour.

\section{Drug interactions}

Although few specific drug interaction studies have been done with TCZ, its potential restorative effect on the expression of CYP450 enzymes in RA patients should be considered when used in combination with known CYP450 substrates that require intense monitoring or have narrow dosing requirements. ${ }^{18}$ In vivo studies showed that omeprazole and simvastatin levels decreased by $28 \%$ and $57 \% 1$ week after TCZ infusion. ${ }^{18}$ Upon initiation or discontinuation of TCZ, drugs with a narrow therapeutic margin (CYP450 substrate) such as warfarin should be closely monitored. ${ }^{18}$

\section{Key studies of TCZ}

There have been several key clinical trials evaluating the efficacy and safety of TCZ in patients with RA. The primary efficacy endpoint used in all studies was the American College of Rheumatology (ACR) response criteria (ACR20,
ACR50, and ACR70; defined by a $20 \%, 50 \%$, or $70 \%$ clinical improvement from baseline after treatment, respectively). ${ }^{23}$ Other endpoints used included the Disease Activity Score of 28 joints (DAS28) improvement criteria, the Health Assessment Questionnaire Disease Index (HAQ-DI) score ${ }^{24}$ and the Sharp score of joint damage. ${ }^{24}$

\section{SATORI: monotherapy - DMARD failure}

The SATORI study (study of active-controlled TCZ monotherapy for RA patients with inadequate response to MTX) was a randomized, double-blind, multicenter Phase III trial that investigated the clinical efficacy and safety of TCZ monotherapy in active RA patients with an inadequate response to low-dose MTX. ${ }^{25}$ This trial consisted of 125 patients who were randomized to receive either TCZ $8 \mathrm{mg} / \mathrm{kg}$ every 4 weeks plus MTX placebo (TCZ group) or TCZ placebo plus MTX $9 \mathrm{mg} /$ week (control group) for 24 weeks. The clinical responses were measured using the ACR criteria and DAS28 response criteria. Serum VEGF levels were also monitored..$^{25}$

An ACR20 response was achieved by $25 \%$ and $80.3 \%$ of patients at week 24 in the control group and TCZ group, respectively. The TCZ group showed superior ACR50 and ACR70 responses over the control group as well from 4 weeks onward. DAS28 scores showed a reduction that was significantly greater for the TCZ group $(P<0.001)$. Additionally, serum VEGF levels were significantly decreased by TCZ treatment $(P<0.001)$. In the TCZ group, increases in total cholesterol (TC), triglycerides (TG), and low-density lipoprotein cholesterol (LDL) were common. Values increased until week 4 and thereafter remained constant. The SATORI study group concluded that TCZ monotherapy was well-tolerated and provided an excellent clinical benefit in active RA patients with an inadequate response to low-dose MTX. ${ }^{25}$

\section{SAMURAI: monotherapy - DMARD failure; radiographic progression with TCZ}

The SAMURAI study (study of active controlled monotherapy used for RA, an IL-6 inhibitor) was an open-label, randomized, placebo-controlled Phase III trial that evaluated the ability of TCZ monotherapy to inhibit progression of structural joint damage in patients with RA. ${ }^{26}$ The trial consisted of 306 patients with active RA of $<5$ years duration who were randomized to receive either TCZ $8 \mathrm{mg} / \mathrm{kg}$ monotherapy or conventional DMARDs (except 
for leflunomide and anti-TNF therapies) for 52 weeks. Radiographs of hands and feet were scored by the van der Heijde modified Sharp method. ${ }^{26}$

In the primary efficacy analysis, the TCZ group showed significantly less radiographic disease progression than those patients treated with conventional DMARDs. At week 52, the secondary endpoints of ACR20, ACR50, and ACR70 response were $78 \%, 64 \%$, and $44 \%$, respectively; which was statistically superior compared to the conventional DMARD group, which was $34 \%, 13 \%$, and $6 \%$, respectively $(P<0.001$, for each comparison). DAS28 remission was achieved in 59\% of patients receiving TCZ compared to $3 \%$ of patients receiving DMARDs at week 52. Laboratory abnormalities were more common in the TCZ group (61\% of subjects) compared to the DMARD group (31\% of subjects). The most common laboratory abnormalities in the TCZ group were related to TC, TG, high-density lipoprotein (HDL) deficiency, and LDL; however, adverse cardiovascular events were not reported. The SAMURAI study concluded that TCZ monotherapy was generally well-tolerated and provided radiographic benefit in patients with RA. ${ }^{26}$

\section{LITHE: combination therapy - DMARD failure; radiographic progression with TCZ}

The LITHE study (TCZ safety and the prevention of structural joint damage) was a double-blind, randomized controlled Phase III trial aiming to assess the efficacy and safety of TCZ in combination with MTX in preventing structural joint damage and improving physical function and disease activity in patients with RA. ${ }^{27}$ The study included a total of 1,196 patients with active, moderate to severe RA, who had an incomplete response to MTX and had not previously failed anti-TNF therapy. Patients were randomized to one of three treatment arms: infusions of either TCZ $4 \mathrm{mg} / \mathrm{kg}$, TCZ $8 \mathrm{mg} / \mathrm{kg}$, or a TCZ placebo every 4 weeks, all in combination with MTX 10-25 mg weekly. The length of the study was 2 years. The main outcomes measured were the changes from baseline in Genant-modified Sharp score and the area under the curve in the HAQ-DI. Secondary endpoints of disease activity using the ACR response criteria were also assessed. $^{27}$

The study found that TCZ significantly inhibited the progression of joint damage in patients with RA (inhibition of radiographic progression compared to control was $74 \%$ in the TCZ $8 \mathrm{mg} / \mathrm{kg}$ group). Also, after 24 weeks of treatment, TCZ $8 \mathrm{mg} / \mathrm{kg}$ plus MTX significantly reduced signs and symptoms compared with MTX monotherapy assessed by ACR responses (ACR20 57\% versus 27\%; ACR50 32\% versus 10\%; ACR70 13\% versus 2\%, respectively; $P<0.0001$ ). By 52 weeks, DAS28 remission rates were significantly higher in the TCZ $8 \mathrm{mg} / \mathrm{kg}$ group at $47.2 \%$ versus $30.2 \%$ in the TCZ $8 \mathrm{mg} / \mathrm{kg}$ group and $7.9 \%$ in the placebo group. The LITHE study group concluded that TCZ plus MTX resulted in greater inhibition of joint damage and greater improvement in physical function than MTX alone. ${ }^{27}$

\section{CHARISMA: combination therapy - previous DMARD failure}

The CHARISMA study (Chugai humanized antihuman recombinant IL-6 monoclonal antibody study) was a randomized, double-blind, placebo-controlled, multicenter, Phase II trial studying the safety and efficacy of repeat infusions of TCZ alone and in combination with MTX. ${ }^{28}$ This trial comprised 359 patients with active RA with inadequate response to 4 weeks of treatment with MTX. Patients were randomized to one of seven treatment arms: TCZ at doses of $2 \mathrm{mg} / \mathrm{kg}, 4 \mathrm{mg} / \mathrm{kg}$, and $8 \mathrm{mg} / \mathrm{kg}$ either as monotherapy with placebo or in combination with MTX, or MTX plus placebo for 20 weeks. $^{28}$

An ACR20 response was achieved by $61 \%$ and $63 \%$ of patients receiving $4 \mathrm{mg} / \mathrm{kg}$ and $8 \mathrm{mg} / \mathrm{kg}$ of TCZ as monotherapy, respectively, and by $63 \%$ and $74 \%$ of patients receiving those doses of TCZ plus MTX, respectively, compared with $41 \%$ of patients receiving placebo plus MTX. Statistically significant ACR50 and ACR70 responses were observed in patients receiving combination therapy with either $4 \mathrm{mg} / \mathrm{kg}$ or $8 \mathrm{mg} / \mathrm{kg}$ of TCZ plus MTX $(P<0.05) .{ }^{28}$

A dose-related reduction in the DAS28 was observed from week 4 onward, in all patients except those receiving monotherapy with $2 \mathrm{mg} / \mathrm{kg}$ of TCZ. Liver transaminases including alanine transaminase and aspartate transaminase levels rose and then fell between TCZ infusions. There were moderate but reversible increases in the non-fasting TC and TG levels and reversible reductions in the HDL cholesterol. The CHARISMA study concluded that TCZ was highly efficacious in decreasing disease activity in RA. ${ }^{28}$

\section{OPTION: combination therapy - previous DMARD failure}

The OPTION study (TCZ pivotal trial in MTX inadequate responders) was a double blind, randomized, placebocontrolled, parallel-grouped Phase III trial studying the efficacy and safety of TCZ. ${ }^{29}$ The trial consisted of 623 patients with active RA with an inadequate response to a stable dose of MTX (10-25 mg/week) for at least 8 weeks. 
Patients were randomized to receive placebo, TCZ $4 \mathrm{mg} / \mathrm{kg}$, or TCZ $8 \mathrm{mg} / \mathrm{kg}$ intravenously every 4 weeks, in combination with weekly stable dose of MTX for 24 weeks. All other DMARDs were discontinued before the start of the study. ${ }^{29}$

The primary endpoint was ACR20 response at week 24, which was significantly higher in the TCZ $4 \mathrm{mg} / \mathrm{kg}$ and TCZ $8 \mathrm{mg} / \mathrm{kg}$ groups compared to the placebo group (48\%, 59\%, and $26 \%$, respectively, $P<0.0001)$. The ACR50 and ACR70 responses were also significantly higher in both the TCZ groups compared to the placebo. DAS28 disease remission was reached by $13 \%, 27 \%$, and $0.8 \%$ of patients in the TCZ $4 \mathrm{mg} / \mathrm{kg}$, TCZ $8 \mathrm{mg} / \mathrm{kg}$, and placebo groups, respectively $(P<0.05)$. The OPTION study concluded that TCZ was an effective therapeutic approach in patients with moderate to severe active RA. ${ }^{29}$

\section{TOWARD: combination therapy - previous DMARD failure}

The TOWARD study (the TCZ in combination with traditional DMARD therapy study) was the largest multicenter randomized, double-blind placebo-controlled study to date investigating the efficacy and safety of TCZ combined with conventional DMARDs (MTX, hydroxychloroquine, parenteral gold, sulfasalazine, azathioprine, and leflunomide) in patients with active RA. ${ }^{30}$ The study excluded patients who had an inadequate response to anti-TNF therapies. A total of 1,220 patients were included in the trial and randomized in a $2: 1$ manner to receive either TCZ $8 \mathrm{mg} / \mathrm{kg}$ infusions or placebo infusions every 4 weeks. All patients continued their conventional DMARD therapy at a stable dose. The primary efficacy endpoint was meeting the ACR20 criteria after 24 weeks. ${ }^{30}$

At week 24, the ACR20 response rate was $61 \%$ in the TCZ group compared to $25 \%$ in the placebo. ACR50 and ACR70 response rates in the TCZ group were $38 \%$ and $21 \%$, respectively; all significantly increased compared to placebo rates of $9 \%$ and $3 \%$, respectively. DAS 28 remission at week 24 was higher in the TCZ group versus the control group (30\% versus $3 \%$, respectively, $P<0.0001)$. There were also greater improvements from baseline in physical function and fatigue with the TCZ group than the placebo group, as assessed by HAQ-DI scores. Elevations in alanine aminotransferase level, from normal at baseline to greater than three-fold the upper limit of normal, occurred in $4 \%$ of patients in the TCZ group and 1\% in the control group, and elevated TC levels were observed in $23 \%$ and $6 \%$ of patients, respectively. Grade III neutropenia occurred in $3.7 \%$ of patients receiving TCZ and none in the control; however, the neutropenias reported were not clearly linked to any serious infections during the course of the trial. The TOWARD study concluded that TCZ combined with any of the DMARDs evaluated was safe and effective in reducing articular and systemic symptoms in patients with an inadequate response to these DMARDs alone. ${ }^{30}$

\section{ROSE: combination therapy - previous DMARD failure}

The ROSE study (the rapid onset and systemic efficacy study) was a randomized, double-blind, placebo-controlled, parallel-group, multicenter Phase III clinical trial evaluating the efficacy of TC in US patients with moderate to severe active RA and inadequate clinical response to DMARDs. ${ }^{31}$ A total of 619 patients were included and randomized 2:1 to TCZ $8 \mathrm{mg} / \mathrm{kg}$ or placebo every 4 weeks while continuing background DMARD in both groups. Permitted DMARDs (at stable doses $>7$ weeks before study baseline) included MTX, hydroxychloroquine, parenteral gold, sulfasalazine, azathioprine, and leflunomide. The primary efficacy endpoint was the ACR50 response at week 24. ${ }^{31}$

At week 24, the ACR50 response was significantly higher in the TCZ group than in the placebo group (30.1\% versus $11.2 \%, P<0.0001)$. Percentages of both ACR 20 and ACR50 responders were significantly higher in the TCZ group versus the placebo group as early as week 4 and continued to week 24 . The proportion of patients achieving a clinically meaningful decrease in DAS28 ( $\geq 1.2$ points from baseline) was significantly higher in the TCZ group versus placebo group at all time points from week 4 onwards $(87.9 \%$ in the TCZ group versus $53.4 \%$ in the placebo group at week $24, P<0.0001$ ). The ROSE study demonstrated the efficacy of TCZ in improving measures of disease activity in patients with RA who failed to respond adequately to DMARD therapy. ${ }^{31}$

\section{RADIATE: combination therapy - previous anti-TNF failure}

The RADIATE study (RA study in anti-TNF failures) was a double-blind, placebo-controlled, multicenter Phase III trial evaluating the efficacy and safety of TCZ in patients with active RA refractory to anti-TNF therapies. ${ }^{32}$ The trial consisted of 499 RA patients with inadequate response to one or more anti-TNF agents. Patients were randomly assigned to one of three treatment arms: TCZ $4 \mathrm{mg} / \mathrm{kg}$, TCZ $8 \mathrm{mg} / \mathrm{kg}$, or placebo infusions every 4 weeks, all with stable doses of MTX (10-25 mg/week) for a total of 24 weeks. The primary efficacy endpoint was meeting the ACR20 response criteria 24 weeks after treatment. ${ }^{32}$ 
At week 24, the proportion of patients achieving an ACR20 was significantly higher in the TCZ $4 \mathrm{mg} / \mathrm{kg}$ and TCZ $8 \mathrm{mg} / \mathrm{kg}$ groups compared to the placebo group (30.4\%, $50.0 \%$, and $10.1 \%$, respectively, $P<0.001)$. The ACR50 and ACR70 responses were also significantly more common in the TCZ $8 \mathrm{mg} / \mathrm{kg}$ group compared to the placebo. The DAS28 remission rates were likewise significantly higher with TCZ $8 \mathrm{mg} / \mathrm{kg}$ at $30.1 \%$ compared to the placebo group (only 1.6\%). Greater improvement in HAQ-DI values from baseline were achieved by the TCZ $8 \mathrm{mg} / \mathrm{kg}$ group and the $\mathrm{TCZ} 4 \mathrm{mg} / \mathrm{kg}$ group compared to the placebo group as well. The most common adverse effects with higher incidence in the TCZ groups were infections, gastrointestinal symptoms, rash, and headache. The RADIATE study concluded that TCZ plus MTX was effective in achieving rapid and sustained improvements in the signs and symptoms of RA in patients with an inadequate response to anti-TNF therapy. ${ }^{32}$

\section{ACT-RAY: monotherapy or combination therapy - previous DMARD failure}

The ACT-RAY study was a double-blind, randomized, placebo-controlled, parallel-group Phase III clinical trial evaluating patients with active RA with inadequate response to MTX, comparing the efficacy of adding TCZ to that of switching to TCZ monotherapy. ${ }^{33}$ The trial included 556 patients who were randomized to either continue MTX with the addition of TCZ $8 \mathrm{mg} / \mathrm{kg}$ every 4 weeks or to switch to TCZ and placebo. The primary endpoint of this study was to achieve DAS28 remission at week $24 .{ }^{33}$

The results showed at week 24 that TCZ monotherapy had comparable efficacy to TCZ plus MTX in patients with an inadequate response to MTX. The DAS28 remission rate was $35 \%$ for the TCZ monotherapy group and $40 \%$ in the TCZ plus MTX group.

The study demonstrated the fast onset of action of TCZ with $18.1 \%$ and $15.2 \%$ of patients achieving remission at week 8 in the combination and monotherapy groups respectively. No overt differences in the safety profile were observed between the two treatments. The ACT-RAY study concluded no clinically relevant superiority of the TCZ plus MTX add-on strategy over the switch to TCZ monotherapy strategy was observed. ${ }^{33}$

\section{ACT-STAR: monotherapy or combination therapy - previous DMARD failure}

The ACT-STAR study was a double-blind, randomized, multicenter Phase III trial in the US that assessed the safety and tolerability of TCZ as monotherapy or in combination with non-biologic DMARDs in patients with moderate to severe RA who had an inadequate response to their current treatment with biologic agents or DMARDs. ${ }^{34}$ The trial included 886 patients who were randomized to TCZ $8 \mathrm{mg} / \mathrm{kg}$ monotherapy, TCZ $4 \mathrm{mg} / \mathrm{kg}$ plus DMARDs, or TCZ $8 \mathrm{mg} / \mathrm{kg}$ plus DMARDs for a total of 24 weeks. Overall, $82.5 \%$ of the patients completed the 24-week study. The primary endpoint was the number and percentage of patients with serious adverse events during 24 weeks of TCZ treatment. Efficacy assessments were evaluated as secondary outcomes. ${ }^{34}$

The serious adverse events per 100 person-years were 28.3 and were similar among the treatment groups. The most common serious adverse events were pneumonia and cellulitis. Overall, ACR20, ACR50, and ACR70 response rates increased throughout the 24-week treatment period and were similar for all treatment groups. Mean DAS28 scores were significantly decreased from baseline at all time points in all treatment groups. The ACT-STAR study concluded that the safety findings were consistent with the previously identified safety profile of TCZ. TCZ had an adverse effect profile consistent with prior randomized blinded studies and was effective when administered as either monotherapy or in combination with DMARDs for the treatment of RA. ${ }^{34}$

\section{AMBITION: monotherapy - no previous MTX or anti-TNF failure}

The AMBITION study (ACTEMRA ${ }^{\circledR}$ versus MTX double blind investigative trial in monotherapy) is a non-inferiority, double-blind, randomized, double-dummy, parallel-group Phase III study that sought to compare TCZ $8 \mathrm{mg} / \mathrm{kg}$ monotherapy to escalating doses of MTX in patients who had not previously failed MTX or biologics. ${ }^{35} \mathrm{~A}$ total of 673 patients were randomized to either TCZ $8 \mathrm{mg} / \mathrm{kg}$ intravenously every 4 weeks or to MTX weekly (escalating dose regimen: initial 7.5 $\mathrm{mg}$, increasing to $15 \mathrm{mg}$ at week 4 and to $20 \mathrm{mg}$ at week 8), and most completed 24 weeks of treatment. Most patients were MTX-naïve with mean disease duration of 5 years. The primary efficacy endpoint was meeting the ACR20 response criteria 24 weeks after treatment. ${ }^{35}$

An ACR20 response was statistically superior in those who received TCZ (70\%) compared to those in the MTX group (52.5\%). The percentage of patients who achieved a DAS28 $<2.6$ was also significantly higher in the TCZ monotherapy group (34\%) compared to the MTX group $(12 \%)$. Health-related quality of life was also better in a higher proportion of patients treated with TCZ monotherapy compared to MTX. There was no significant difference in 
the incidence of serious adverse events with TCZ versus MTX, but in the TCZ group, there was a higher incidence of reversible grade III neutropenia (3.1\% versus $0.4 \%)$ and increased TC (13.2\% versus $0.4 \%)$ relative to placebo. The AMBITION study concluded that TCZ monotherapy is better than MTX monotherapy, with rapid improvement in RA signs and symptoms and a favorable benefit-risk profile, in patients for whom treatment with MTX or biological agents has not previously failed. ${ }^{35}$

\section{ADACTA: monotherapy versus anti-TNF}

The ADACTA study was a double-blind, randomized, placebo-controlled multicenter Phase IV trial that was the first head-to-head trial specifically designed to determine superiority between two biologic medications as monotherapy for the treatment of RA. ${ }^{36}$ This trial evaluated the efficacy and safety of TCZ monotherapy versus adalimumab monotherapy for the treatment of biologic-naïve patients with severe RA (DAS28 < 5.1) who were intolerant of MTX or for whom MTX was inappropriate. A total of 326 patients were randomized to receive either TCZ $8 \mathrm{mg} / \mathrm{kg}$ every 4 weeks or adalimumab $40 \mathrm{mg}$ subcutaneously every 2 weeks for 24 weeks total. The primary efficacy outcome was the mean change from baseline in DAS28 at week $24 .^{36}$

At week 24, the mean change from baseline in DAS28 was significantly greater in the TCZ group $(-3.3)$ than in the adalimumab group $(-1.8) ; P<0.0001$. Ten percent of patients in the adalimumab group versus $12 \%$ in the TCZ group had serious adverse events. More patients in the TCZ group had increased LDL cholesterol, increased alanine aminotransferase concentrations, and reduced platelet and neutrophil counts. The ADACTA study concluded that TCZ monotherapy was superior to adalimumab monotherapy for reduction of signs and symptoms of RA in patients for whom MTX was deemed inappropriate. ${ }^{36}$

\section{MUSASHI: monotherapy - subcutaneous TCZ (TCZ-SC) versus intravenous TCZ (TCZ-IV) infusion - previous DMARD failure}

The MUSASHI study (multicenter double-blind study of ACTEMRA subcutaneous injection in patients having RA to verify non-inferiority against intravenous infusion) was a 24 week, randomized, double-blind, Phase III trial designed to evaluate the efficacious non-inferiority of TCZ-SC injection monotherapy to TCZ-IV infusion monotherapy in patients with RA with an inadequate response to synthetic and/or biologic DMARDs. ${ }^{37} \mathrm{~A}$ total of 348 patients were randomized 1:1 into two groups: $162 \mathrm{mg}$ of TCZ-SC monotherapy every 2 weeks plus placebo TCZ-IV every 4 weeks or $8 \mathrm{mg} / \mathrm{kg}$ TCZ monotherapy every 4 weeks plus placebo-TCZ-SC every 2 weeks. The primary endpoint was to evaluate the non-inferiority of TCZ-SC to TCZ-IV regarding ACR20 response rates at week 24 .

At week 24, ACR20 response was achieved in 79.2\% of the TCZ-SC group and $88.5 \%$ of the TCZ-IV group. The incidences of adverse events and serious adverse events were similar in both groups. The MUSASHI study concluded that TCZ-SC had comparable efficacy and safety to TCZ-IV monotherapy, and that TCZ-SC could provide additional treatment options for patients with RA. ${ }^{37}$

\section{SUMMACTA: combination therapy: SC-TCZ versus IV-TCZ - previous DMARD failure}

The SUMMACTA study was a randomized, double-dummy, Phase III, multicenter study with a double-blind study evaluating the efficacy and safety of TCZ-SC versus TCZ-IV in adult patients with RA who had an inadequate response to one or more DMARD. ${ }^{38} \mathrm{~A}$ total of 1,262 patients were randomly assigned to receive TCZ-SC $162 \mathrm{mg}$ weekly plus intravenous placebo every 4 weeks or TCZ-IV $8 \mathrm{mg} / \mathrm{kg}$ every 4 weeks plus subcutaneous placebo weekly in combination with traditional DMARDs. The primary outcome was to evaluate the noninferiority of TCZ-SC to TCZ-IV regarding the proportion of patients who achieved an ACR20 response at week 24.

At week 24, 69.4\% of TCZ-SC patients versus $73.4 \%$ of TCZ-IV treated patients achieved an ACR20 response. The safety profiles of both treatments were similar, and the most common adverse event was infection. Injection site reactions occurred more frequently in the TCZ-SC group than the TCZ-IV group. The SUMMACTA study concluded that TCZ-SC $162 \mathrm{mg}$ weekly demonstrated comparable efficacy to TCZ-IV $8 \mathrm{mg} / \mathrm{kg} .{ }^{38}$

\section{Summary of TCZ trials in RA}

The above trial data shows the efficacy of TCZ in adult patients with active moderate to severe RA. Tables 1 and 2 summarize the key trials from Phase II, III, and IV trials involving TCZ. These trials demonstrate that TCZ was effective in RA treatment in patients both as monotherapy and combination therapy in patients with inadequate response to DMARDs in moderate to severe RA, including inadequate response to MTX and anti-TNF therapy. TCZ at a 
Table I Key trials of tocilizumab

\begin{tabular}{|c|c|c|c|c|c|c|}
\hline Trial & Year & Patients & $\begin{array}{l}\text { Duration } \\
\text { (weeks) }\end{array}$ & Design & Prior treatment & Treatment arms \\
\hline CHARISMA $^{28}$ & 2006 & 359 & 20 & $\begin{array}{l}\text { Double-blind, multicenter, } \\
\text { randomized controlled trial }\end{array}$ & $\begin{array}{l}\text { Inadequate response } \\
\text { to MTX }\end{array}$ & $\begin{array}{l}\text { TCZ } 2 \mathrm{mg} / \mathrm{kg}, 4 \mathrm{mg} / \mathrm{kg} \text {, or } 8 \mathrm{mg} / \mathrm{kg} \\
\text { monthly either as monotherapy or } \\
\text { in combination with MTX }\end{array}$ \\
\hline SAMURAII ${ }^{26}$ & 2007 & 300 & 52 & $\begin{array}{l}\text { X-ray reader-blind, open- } \\
\text { label randomized, placebo- } \\
\text { controlled trial }\end{array}$ & $\begin{array}{l}\text { Failed } \geq \text { I DMARD } \\
\text { No biologic failure }\end{array}$ & TCZ $8 \mathrm{mg} / \mathrm{kg}$ monthly or DMARDs \\
\hline SATORI ${ }^{25}$ & 2008 & 125 & 24 & $\begin{array}{l}\text { Randomized, double-blind, } \\
\text { multicenter, controlled trial }\end{array}$ & $\begin{array}{l}\text { Inadequate response } \\
\text { to MTX } \\
\text { No biologic failure }\end{array}$ & $\begin{array}{l}\text { TCZ } 8 \text { mg/kg monthly }+ \text { MTX } \\
\text { placebo or MTX } 8 \text { mg weekly + } \\
\text { TCZ placebo }\end{array}$ \\
\hline OPTION $^{29}$ & 2008 & 622 & 24 & $\begin{array}{l}\text { Double-blind, randomized, } \\
\text { placebo-controlled trial, } \\
\text { parallel-grouped trial }\end{array}$ & Failed $\geq$ I DMARD & $\begin{array}{l}\text { TCZ } 4 \mathrm{mg} / \mathrm{kg} \text { monthly }+\mathrm{MTX}, \mathrm{TCZ} \\
8 \mathrm{mg} / \mathrm{kg} \text { monthly }+\mathrm{MTX} \text {, or } \\
\text { MTX + placebo }\end{array}$ \\
\hline RADIATE $^{32}$ & 2008 & 489 & 24 & $\begin{array}{l}\text { Double-blind, placebo- } \\
\text { controlled trial }\end{array}$ & $\begin{array}{l}\text { No prior MTX failure } \\
\text { Biologic failure }\end{array}$ & $\begin{array}{l}\text { TCZ } 4 \mathrm{mg} / \mathrm{kg} \text { monthly }+\mathrm{MTX}, \mathrm{TCZ} \\
8 \mathrm{mg} / \mathrm{kg} \text { monthly }+\mathrm{MTX}, \\
\text { or MTX + placebo }\end{array}$ \\
\hline TOWARD $^{30}$ & 2008 & $\mathrm{I}, 220$ & 24 & $\begin{array}{l}\text { Double-blind, randomized, } \\
\text { placebo-controlled, } \\
\text { multicenter trial }\end{array}$ & $\begin{array}{l}\text { Failed } \geq \text { I DMARD } \\
\text { No biologic failure }\end{array}$ & TCZ 8 mg/kg monthly or placebo \\
\hline AMBITION 35 & 2010 & 570 & 24 & $\begin{array}{l}\text { Double-blind, randomized, } \\
\text { double-dummy, parallel- } \\
\text { group study }\end{array}$ & $\begin{array}{l}\text { No previous MTX or } \\
\text { biologic failure }\end{array}$ & $\begin{array}{l}\text { TCZ } 8 \mathrm{mg} / \mathrm{kg} \text { monthly versus } \\
\text { escalating doses of MTX }\end{array}$ \\
\hline LITHE ${ }^{27}$ & 2011 & 1,196 & 104 & $\begin{array}{l}\text { Double-blind, randomized, } \\
\text { controlled trial }\end{array}$ & $\begin{array}{l}\text { Inadequate response } \\
\text { to MTX }\end{array}$ & $\begin{array}{l}\text { TCZ } 4 \mathrm{mg} / \mathrm{kg} \text { monthly }+\mathrm{MTX}, \mathrm{TCZ} \\
8 \mathrm{mg} / \mathrm{kg} \text { monthly }+\mathrm{MTX} \text {, or } \\
\text { placebo + MTX }\end{array}$ \\
\hline $\operatorname{ROSE}^{31}$ & 2011 & 619 & 24 & $\begin{array}{l}\text { Double-blind, randomized, } \\
\text { placebo-controlled, } \\
\text { parallel-group trial }\end{array}$ & $\begin{array}{l}\text { Inadequate response } \\
\text { to DMARDs }\end{array}$ & $\begin{array}{l}\text { TCZ } 8 \mathrm{mg} / \mathrm{kg} \text { monthly }+ \text { stable } \\
\text { DMARDs or placebo }\end{array}$ \\
\hline ACT-RAY ${ }^{33}$ & 2012 & 556 & 24 & $\begin{array}{l}\text { Double-blind, randomized, } \\
\text { placebo-controlled, } \\
\text { parallel-group trial }\end{array}$ & $\begin{array}{l}\text { Inadequate response } \\
\text { to MTX } \\
\text { No biologic failure }\end{array}$ & $\begin{array}{l}\text { TCZ } 8 \mathrm{mg} / \mathrm{kg} \text { monthly + MTX or } \\
\text { TCZ } 8 \mathrm{mg} / \mathrm{kg} \text { monthly + placebo }\end{array}$ \\
\hline $\mathrm{ADACTA}^{36}$ & 2013 & 326 & 24 & $\begin{array}{l}\text { Double-blind, randomized, } \\
\text { multicenter, parallel- } \\
\text { group study }\end{array}$ & $\begin{array}{l}\text { Inadequate response } \\
\text { to MTX } \\
\text { Biologic failure }\end{array}$ & $\begin{array}{l}\text { TCZ } 8 \mathrm{mg} / \mathrm{kg} \text { monthly + placebo or } \\
\text { adalimumab + placebo }\end{array}$ \\
\hline ACT-STAR ${ }^{34}$ & 2013 & 886 & 24 & $\begin{array}{l}\text { Randomized, open-label, } \\
\text { multicenter study }\end{array}$ & $\begin{array}{l}\text { Inadequate response } \\
\text { to DMARDs or } \\
\text { biologic }\end{array}$ & $\begin{array}{l}\text { TCZ } 4 \mathrm{mg} / \mathrm{kg} \text { monthly + DMARDs, } \\
\text { TCZ } 8 \mathrm{mg} / \mathrm{kg} \text { monthly + DMARDs, } \\
\text { or TCZ } 8 \mathrm{mg} / \mathrm{kg} \text { monthly } \\
\text { monotherapy }\end{array}$ \\
\hline
\end{tabular}

Abbreviations: DMARD, disease-modifying antirheumatic drug; MTX, methotrexate; TCZ, tocilizumab.

dose of $8 \mathrm{mg} / \mathrm{kg}$ was shown to be more likely to lead to DAS28 remission and a greater improvement in HAQ-DI scores. ${ }^{39}$ Furthermore, TCZ at a dose of $8 \mathrm{mg} / \mathrm{kg}$ was found to achieve a more sustained target saturation compared to $4 \mathrm{mg} / \mathrm{kg}$, which was associated with improved response based on ACR criteria and tender and swollen joint counts. The sustained receptor-blocking activity and longer half-life with the higher TCZ dose of $8 \mathrm{mg} / \mathrm{kg}$ results in prolonged exposure and may be associated with improved response. ${ }^{40}$ In fact, since the higher dose was consistently superior in clinical trials, many experts recommend initiating treatment at $8 \mathrm{mg} / \mathrm{kg}$ and reducing the dose to $4 \mathrm{mg} / \mathrm{kg}$ only in the event of an adverse effect that requires a dose modification.
In both Europe and Japan, only the $8 \mathrm{mg} / \mathrm{kg}$ dose is approved for initiation of TCZ. The SATORI trial established that TCZ monotherapy was effective in the treatment of RA in patients with inadequate response to low-dose MTX. Multiple studies, including CHARISMA, OPTION, TOWARD, and ROSE, all demonstrated the efficacy of TCZ in combination therapy with other conventional DMARDs in patients with previous DMARD failure. The RADIATE trial was the first trial to look at TCZ in combination with MTX in patients with previous anti-TNF- $\alpha$ failure and found that the combination was effective in patients with an inadequate response to antiTNF- $\alpha$ therapy. The AMBITION trial established superior efficacy of TCZ monotherapy over MTX monotherapy 


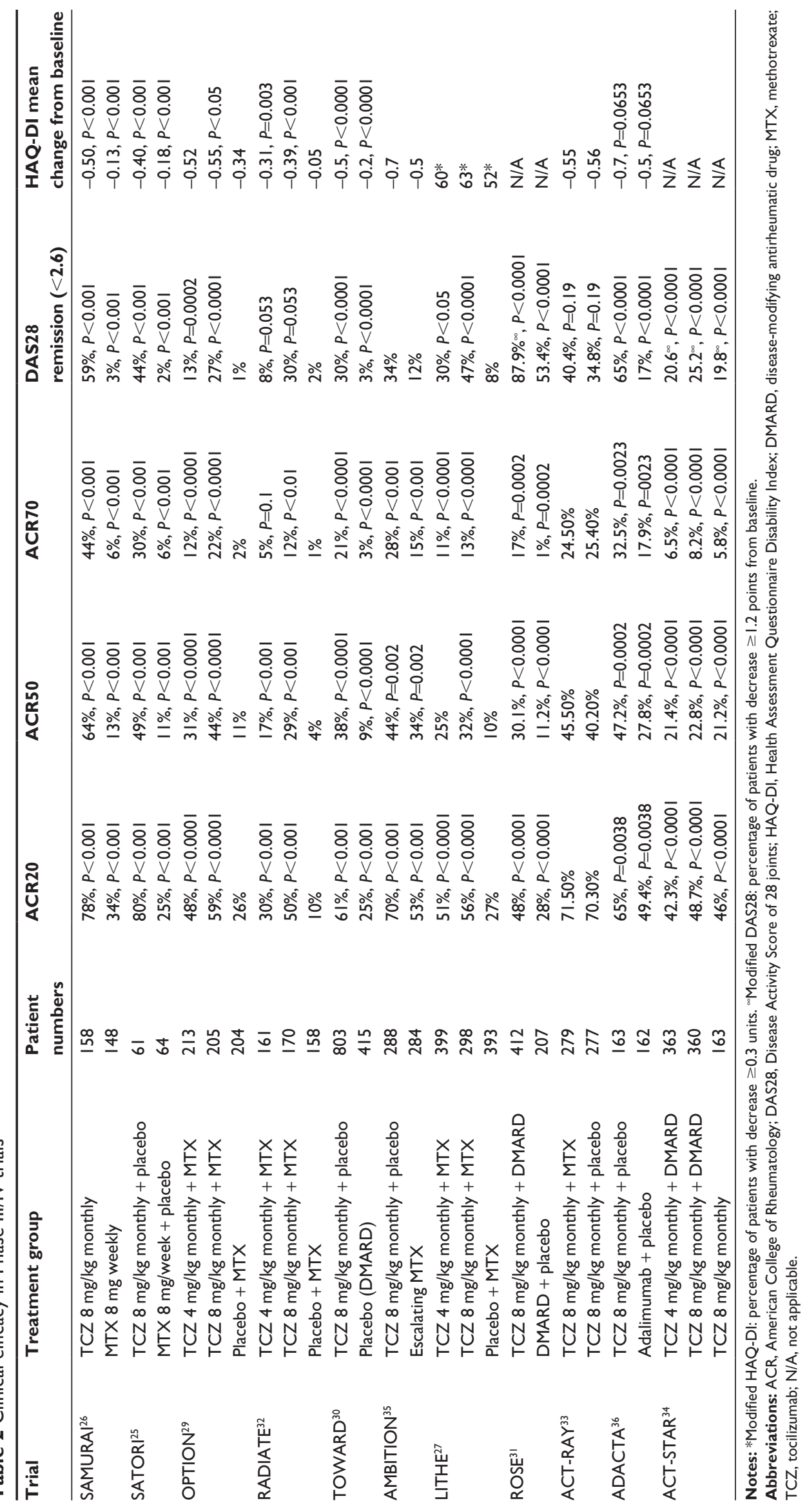


regardless of previous MTX exposure. The ADACTA study found that TCZ monotherapy was superior to adalimumab monotherapy for reduction of signs and symptoms of RA in patients for whom MTX was deemed inappropriate. Both the SAMURAI and LITHE studies looked at radiographic progression of disease with TCZ and concluded that TCZ provided radiographic benefit compared to MTX or other conventional DMARDs alone.

The majority of these studies demonstrated the efficacy of TCZ in moderate to severe active RA with inadequate clinical response to DMARDs or to TNF- $\alpha$ inhibitors. However, in addition, based on the AMBITION trial, TCZ may be considered a first-line therapy in patients with relatively early active RA for whom MTX has not previously failed. This is a question that can only be achieved by conducting studies testing early versus late treatment with TCZ in the same trial. The ADACTA trial also suggests that TCZ is more effective than TNF- $\alpha$ inhibitors, specifically adalimumab, and can be considered as a first-line biologic to be tried prior to TNF- $\alpha$ inhibitors. TCZ-SC recently became FDA-approved in October 2013 for DMARD inadequate responders with moderate to severe RA. The MUSASHI and SUMMACTA trials demonstrated that TCZ-SC had comparable efficacy and clinical safety profiles to TCZ-IV and the subcutaneous formulation provides an additional, more convenient administration option and opportunity for home injection for patients with RA.
There are no trials comparing the efficacy of TCZ to abatacept or rituximab, and the choice of TNF- $\alpha$ inhibitors or biologics with different modes of action after inadequate response to one or more DMARD is generally reliant on physician preference and patient's comorbidities. A metaanalysis comparing the potential adverse effects of nine biologic agents, including adalimumab, certolizumab, etanercept, golimumab, infliximab, anakinra, rituximab, abatacept, and TCZ, found no statistically significant differences between biologics in total adverse effects or withdrawals due to adverse effects. ${ }^{41}$ Thus, all the biologic agents have comparable safety profiles. For this reason, comparative studies addressing biologics as monotherapy are needed, looking at reduction of clinical signs, symptoms, and radiographic progression, while maintaining acceptable safety and tolerability profiles.

\section{Safety and tolerability}

Data on adverse and serious adverse events are shown in Table 3. Overall, the most common adverse events were laboratory abnormalities and infections. ${ }^{42}$ Risk factors associated with acquiring an infection are advanced age, concurrent corticosteroid use, previous exposure to a biologic DMARD such an anti-TNF agent, and history of pulmonary disease. ${ }^{43}$ Therefore, any active localized or disseminated infection should be resolved before initiating TCZ and treatment should be interrupted if an infection is identified. ${ }^{44}$ No cases of

Table 3 Adverse events in Phase III/IV trials

\begin{tabular}{|c|c|c|c|c|c|c|c|}
\hline Trial & Treatment group & Any AEs & Serious AEs & Death & $\begin{array}{l}\text { Serious } \\
\text { infection }\end{array}$ & Neoplasm & $\begin{array}{l}\text { Drug-related } \\
\text { infusion reaction }\end{array}$ \\
\hline \multirow[t]{2}{*}{ SAMURAI ${ }^{26}$} & TCZ 8 mg/kg & $89 \%$ & $18 \%$ & 0 & $5 \%$ & $2 \%$ & $7 \%$ \\
\hline & MTX & $82 \%$ & $13 \%$ & 0 & $4 \%$ & 0 & \\
\hline \multirow[t]{2}{*}{ SATORI $^{25}$} & $\mathrm{TCZ} 8 \mathrm{mg} / \mathrm{kg}$ & $92 \%$ & $7 \%$ & 0 & $2 \%$ & & $11.5 \%$ \\
\hline & Placebo & $72 \%$ & $5 \%$ & 0 & $2 \%$ & & \\
\hline \multirow[t]{3}{*}{ OPTION ${ }^{29}$} & $\mathrm{TCZ} 4 \mathrm{mg} / \mathrm{kg}$ & $71 \%$ & $6 \%$ & 0 & $1 \%$ & 0 & \\
\hline & TCZ 8 mg/kg & $69 \%$ & $6 \%$ & 0 & $3 \%$ & 0 & \\
\hline & Placebo & $63 \%$ & $6 \%$ & 0 & $1 \%$ & $2 \%$ & \\
\hline \multirow[t]{3}{*}{ RADIATE ${ }^{32}$} & $\mathrm{TCZ} 4 \mathrm{mg} / \mathrm{kg}$ & $87 \%$ & $2 \%$ & 0 & $2 \%$ & & $9.8 \%$ \\
\hline & $\mathrm{TCZ} 8 \mathrm{mg} / \mathrm{kg}$ & $84 \%$ & $5 \%$ & 0 & $5 \%$ & & $9.1 \%$ \\
\hline & Placebo & $81 \%$ & $3 \%$ & 0 & $3 \%$ & & $6.3 \%$ \\
\hline \multirow[t]{2}{*}{ TOWARD ${ }^{30}$} & TCZ 8 mg/kg & $73 \%$ & $8 \%$ & $0.30 \%$ & $3 \%$ & & \\
\hline & Placebo & $61 \%$ & $4 \%$ & $0.50 \%$ & $2 \%$ & & \\
\hline \multirow[t]{2}{*}{ AMBITION $^{35}$} & TCZ 8 mg/kg & $80 \%$ & $4 \%$ & $1 \%$ & $1 \%$ & & $5.6 \%$ \\
\hline & Placebo & $78 \%$ & $3 \%$ & $0.40 \%$ & $1 \%$ & & $1.8 \%$ \\
\hline \multirow[t]{2}{*}{$\operatorname{ROSE}^{31}$} & $\mathrm{TCZ} 8 \mathrm{mg} / \mathrm{kg}$ & $71 \%$ & $8.6 \%$ & $1 \%$ & $3 \%$ & $1 \%$ & \\
\hline & Placebo & $60 \%$ & $6.3 \%$ & 0 & 0 & $2 \%$ & \\
\hline \multirow[t]{2}{*}{ ACT-RAY ${ }^{33}$} & $\mathrm{TCZ} 8 \mathrm{mg} / \mathrm{kg}+\mathrm{MTX}$ & $70 \%$ & $6.1 \%$ & $1 \%$ & $2.2 \%$ & & \\
\hline & TCZ 8 mg/kg + placebo & $73 \%$ & $5.8 \%$ & $1 \%$ & $2.2 \%$ & & \\
\hline \multirow[t]{2}{*}{ ADACTA $^{36}$} & TCZ 8 mg/kg & $82 \%$ & $12 \%$ & $1 \%$ & $4 \%$ & $1 \%$ & \\
\hline & Adalimumab & $83 \%$ & $10 \%$ & 0 & $4 \%$ & $1 \%$ & \\
\hline
\end{tabular}

Abbreviations: AE, adverse event; MTX, methotrexate; TCZ, tocilizumab. 
tuberculosis were reported in any of the Phase III trials, which is a known possible side effect in anti-TNF medications. IL-6 does not appear to have an effect on granuloma formation. Neutropenia, thrombocytopenia, and elevated liver enzymes may occur at higher incidence with $\mathrm{TCZ}$ and may require a dose reduction, interruption, or discontinuation depending on the severity. ${ }^{45}$ Additionally, an increase in TC, TG, and LDL may occur, possibly due to attenuated lipolysis and reduced hepatic LDL receptor expression; this is typically evident by week 6 and may require treatment with statin therapy if clinically significant elevations occur. ${ }^{46}$ With respect to leukocytopenia, TCZ should be discontinued if neutrophil counts are $<500 \mathrm{~mm}^{3}$. In the 6-month Phase III trials, authors reported no clear relationship between decreases in neutrophils $<1,000 \mathrm{~mm}^{3}$ and the occurrence of serious infections or neutropenic fever. ${ }^{47}$ Complete blood count with differential, liver profile, and lipid levels should be assessed every 4 to 8 weeks for the first 6 months and every 3 months thereafter. ${ }^{48}$ Considering the known increased higher incidence of cardiovascular mortality in RA patients, traditional risk factors for cardiovascular disease, including dyslipidemia, are not necessarily predictive of events for patients with RA. ${ }^{49}$ Despite the lipid abnormalities seen with TCZ, clinical cardiovascular events have not been increased with TCZ therapy in the trials and no studies have been published assessing LDL particle size. Furthermore, some evidence suggests use of TCZ may reduce arterial stiffness similar to other biologics, and also may reduce serum levels of the cardiovascular disease promoting lipoprotein(a). ${ }^{50}$ Additional risks to assess for include gastrointestinal perforations, malignancies, liver disease, and demyelinating diseases. All of these have been reported in association with TCZ. ${ }^{51}$ Although possibly higher than with conventional DMARDs or anti-TNF therapies, the data suggest the overall risk of gastrointestinal perforation with the use of TCZ is low and risk may be amplified by concomitant use of NSAIDs or corticosteroids. ${ }^{52}$ The risk of serious adverse events does not appear to increase with prolonged exposure to TCZ; in fact, most adverse events leading to discontinuation occur during the first 6 months of treatment, the most common being infection and elevation of liver enzymes. ${ }^{53}$ Administering live vaccinations during treatment with TCZ has not been studied and it is recommended that any live vaccines be given at a minimum of 4 weeks prior to treatment initiation.

The ACT-SURE study, a 24-week, Phase IIIb, open-label, single-arm study, in which patients received TCZ-IV $8 \mathrm{mg} / \mathrm{kg}$ every 4 weeks, evaluated the safety of TCZ in clinical practice in a total of 1,680 patients with RA with inadequate responses to DMARDs or both DMARDs and TNF- $\alpha$ inhibitors. ${ }^{54}$ In this study, the incidence of infection and other adverse events at the rate of 5.2 serious infections per 100 patients-years was similar to that previously reported in RA patients taking anti-TNF agents. ${ }^{55}$

\section{Future directions}

TCZ has the potential of being used in various other autoimmune diseases including systemic juvenile idiopathic arthritis (sJIA), adult-onset Still's disease (AOSD), and systemic lupus erythematosus (SLE) ${ }^{56}$ IL-6 may play a role in the pathogenesis of these diseases. In a randomized, double-blind study of 56 children with sJIA, three doses of $8 \mathrm{mg} / \mathrm{kg}$ were administered every 2 weeks and $75 \%$ of the TCZ group patients reached an ACR70 endpoint and lower C-reactive protein levels compared to $13 \%$ in the placebo group. ${ }^{57}$ In Japan, TCZ has been approved for sJIA treatment. AOSD shares many of the clinical symptoms of sJIA, including fever spikes, arthralgia or arthritis, myalgia, evanescent rashes, and splenomegaly. In AOSD, IL-6 serum level has been shown to correlate with clinical disease activity and has also been found in tissues of affected patients. ${ }^{58}$ One study looked at 14 patients with AOSD refractory to other therapies who were started on TCZ and eight out of 14 patients achieved DAS remission. ${ }^{59}$ TCZ treatment was also shown to induce TCZ-free remission in patients, and retreatment with TCZ following a long-term interval resulted in an efficacy similar to the first-time treatment. ${ }^{60}$ Previous studies have associated SLE disease activity with increased serum IL-6 levels in patients. ${ }^{61}$ In patients with SLE, a small Phase I, open-label study of 16 patients with moderate lupus received TCZ with a significant decrease in clinical symptoms. ${ }^{62}$ More studies are needed to further assess the therapeutic benefits of TCZ for the treatment of SLE.

IL-6 is implicated in vascular inflammation and injury in Takayasu arteritis (TA). Strong expression of IL-6 has been shown in the aorta and serum levels of IL- 6 have been reported to be greatly elevated in patients with TA and could correlate with disease activity. ${ }^{63}$ A retrospective study of TCZ in seven consecutive patients with refractory TA concluded that TCZ may be effective in a subset of patients with refractory TA, even in cases of unresponsiveness to TNF- $\alpha$ inhibitors. ${ }^{64}$ Another retrospective study including 44 patients with TA treated with TCZ showed the efficacy of TCZ in terms of clinical, biological, and radiographical response, as well as a steroid-sparing agent in the treatment of TA. ${ }^{65}$ These studies demonstrated that TCZ may represent an alternative therapeutic option even in refractory TA. A multicenter, randomized, controlled trial may be necessary 
to address the benefits of first-line TCZ treatment in inducing remission and steroid sparing, as well as to compare the best strategy for biologics in TA.

Sarcoidosis, a multisystem autoimmune disorder with incompletely understood pathophysiology, has been associated with elevated levels of IL-6 in bronchoalveolar fluid ${ }^{66}$ and induced sputum, ${ }^{67}$ making IL-6 theoretically a potential target in sarcoidosis. However, there is no established role for TCZ in sarcoidosis since there is also one report of new-onset sarcoidosis which occurred after treatment with TCZ for RA. ${ }^{68}$

Additionally, IL-6 may be a biomarker of carotid artery atherosclerosis in patients with moderate to high prevalence of coronary artery disease.$^{69}$ One study showed TCZ reduced arterial stiffness, although TC increased. Higher cholesterol may be secondary to increased HDL cholesterol so that the TC/HDL ratio did not change. ${ }^{70}$ High levels of IL- 6 have also been found to be a predictor of stroke in patients with atrial fibrillation. ${ }^{71}$ IL-6 is thought to play a crucial role in the radicular pain caused by lumbar spinal stenosis. One small randomized study looked at the effect of TCZ on radicular pain by its epidural administration in 60 patients with lumbar spinal stenosis. ${ }^{72}$ The study concluded that epidural administration of TCZ produced reduction of radicular leg pain, numbness, and low back pain without adverse events. ${ }^{72}$

Elevations in serum and tissue IL- 6 concentrations have been reported in numerous malignancies including liver, gastric, brain, ovarian, and pancreatic cancers. Evidence suggests increased IL-6 may affect development and disease pathogenesis, reduce response to treatment, and be a marker for prognosis. ${ }^{73}$ For example, in the instance of hepatocellular carcinoma, higher serum IL-6 levels are associated with advanced disease, reduced survival, and increased tumor size. ${ }^{74}$ Additionally, the presence of elevated IL-6 serum levels is shown to be an independent risk factor for developing hepatocellular carcinoma. ${ }^{75}$ Inhibiting IL-6 with TCZ is thought to be a promising target in cancer treatment and has been preliminarily studied in animal models. ${ }^{76}$ Finally, IL-6 is an attractive target in solid organ transplantation, hence its effect on B cell stimulation and antibody production. ${ }^{77}$ Blocking IL-6 could theoretically lead to a lower rate of transplant rejection. To date, there is one Phase I/II clinical trial that investigates the usefulness of TCZ in kidney transplantation ${ }^{78}$ and another Phase II trial in patients with glucocorticoid-refractory acute graft-versus-host disease after hematopoietic stem cell transplant. ${ }^{79}$

\section{Conclusion}

TCZ is currently the only FDA-approved drug targeting IL-6 receptors. Phase III studies are underway for two new IL-6 antagonists, sarilumab and sirukumab, for the treatment of RA. ${ }^{80,81}$ Sarilumab, the first fully humanized monoclonal antibody directed against IL-6 receptor alpha, demonstrated encouraging results in Phase II studies when used in combination with MTX. ${ }^{82}$ Additionally sirukumab proved to be efficacious and well-tolerated in combination with MTX in a Phase II, proof of concept study. ${ }^{83}$ The clinical trials reviewed in this article provide strong evidence that TCZ's use, both as monotherapy and in combination with MTX or other DMARDs, is an effective treatment in reducing the signs and symptoms of RA. Additionally, TCZ reduced radiological disease progression and improved physical function. TCZ safety concerns include elevated liver enzymes, elevated LDL, infections, and gastrointestinal perforations. Given that these trials analyzed short-term efficacy and safety profiles, further long-term safety data are required to better characterize the risk-benefit profile of TCZ. With the advances in treatment of RA, biologics targeting differing proinflammatory cytokines may offer new utility in patients who have failed treatment with previous DMARDs. Given its clinical efficacy in the treatment of RA, TCZ may be beneficial in the treatment of other autoimmune diseases, spinal disease, cardiovascular disease, organ transplantation, sarcoidosis, and malignancies where elevated levels of IL-6 play a role.

\section{Disclosure}

The authors report no conflicts of interest in this work.

\section{References}

1. Helmick CG, Felson DT, Lawrence RC, et al; National Arthritis Data Workgroup. Estimates of the prevalence of arthritis and other rheumatic conditions in the United States. Part I. Arthritis Rheum. 2008;58(1):15-25.

2. Majithia V, Geraci SA. Rheumatoid arthritis: diagnosis and management. Am J Med. 2007;120(11):936-939.

3. Smolen JS, Aletaha D, Koeller M, Weisman MH, Emery P. New therapies for treatment of rheumatoid arthritis. Lancet. 2007;370(9602): 1861-1874.

4. Jackson CG, Williams HJ. Disease-modifying antirheumatic drugs. Using their clinical pharmacological effects as a guide to their selection. Drugs. 1998;56(3):337-344.

5. Elliott MJ, Maini RN, Feldmann M, et al. Randomised double-blind comparison of chimeric monoclonal antibody to tumour necrosis factor alpha (cA2) versus placebo in rheumatoid arthritis. Lancet. 1994;344(8930):1105-1110.

6. Nam JL, Winthrop KL, van Vollenhoven RF, et al. Current evidence for the management of rheumatoid arthritis with biological disease-modifying antirheumatic drugs: a systematic literature review informing the EULAR recommendations for the management of RA. Ann Rheum Dis. 2010;69(6):976-986.

7. Boers M. Cost-effectiveness of biologics as first-line treatment of rheumatoid arthritis: case closed? Ann Intern Med. 2009;151(9):668-669.

8. Nishimoto N, Kishimoto T. Humanized antihuman IL-6 receptor antibody, tocilizumab. Handb Exp Pharmacol. 2008;(181):151-160.

9. Kishimoto T. Interleukin-6: from basic science to medicine -40 years in immunology. Аnпu Rev Immunol. 2005;23:1-21. 
10. Hirano T, Matsuda T, Turner M, et al. Excessive production of interleukin 6/B cell stimulatory factor-2 in rheumatoid arthritis. Eur J Immunol. 1988;18(11):1797-1801.

11. Shahrara S, Huang Q, Mandelin AM 2nd, Pope RM. TH-17 cells in rheumatoid arthritis. Arthritis Res Ther. 2008;10(4):R93.

12. Sack U, Kinne RW, Marx T, Heppt P, Bender S, Emmrich F. Interleukin-6 in synovial fluid is closely associated with chronic synovitis in rheumatoid arthritis. Rheumatol Int. 1993;13(2):45-51.

13. Kotake S, Sato K, Kim KJ, et al. Interleukin- 6 and soluble interleukin-6 receptors in the synovial fluids from rheumatoid arthritis patients are responsible for osteoclast-like cell formation. J Bone Miner Res. 1996;11(1):88-95.

14. Mihara M, Kasutani K, Okazaki M, et al. Tocilizumab inhibits signal transduction mediated by both mIL-6R and sIL-6R, but not by the receptors of other members of IL-6 cytokine family. Int Immunopharmacol. 2005;5(12):1731-1740.

15. Choy EH, Isenberg DA, Garrood T, et al. Therapeutic benefit of blocking interleukin-6 activity with an anti-interleukin-6 receptor monoclonal antibody in rheumatoid arthritis: a randomized, double-blind, placebo-controlled, dose-escalation trial. Arthritis Rheum. 2002;46(12):3143-3150.

16. American College of Rheumatology Committee to Reevaluate Improvement Criteria. A proposed revision to the ACR20: the hybrid measure of American College of Rheumatology response. Arthritis Rheum. 2007;57(2):193-202.

17. Navarro-Millán I, Singh JA, Curtis JR. Systematic review of tocilizumab for rheumatoid arthritis: a new biologic agent targeting the interleukin-6 receptor. Clin Ther. 2012;34(4):788-802. e3.

18. Roche (2009) RoACTEMRA [summary of product characteristics] prescribing information. Welwyn Garden City: Roche Registration Limited, January 2009.

19. Levi M, Grange S, Frey N. Exposure-response relationship of tocilizumab, an anti-IL-6 receptor monoclonal antibody, in a large population of patients with rheumatoid arthritis. J Clin Pharmacol. 2013;53(2):151-159.

20. Actemra ${ }^{\circledR}$ (tocilizumab) [prescribing information]. South San Francisco: Genentech, Inc.; 2010.

21. European Medicines Agency. Assessment Report for RoActemra. London: European Medicines Agency; 2011. Available from: http://www.ema.europa.eu/docs/en_GB/document_library/ EPAR_-_Assessment_Report_-_Variation/human/000955/ WC500111086.pdf. Accessed January 23, 2014.

22. Smolen JS, Landewé R, Breedveld FC, et al. EULAR recommendations for the management of rheumatoid arthritis with synthetic and biological disease-modifying antirheumatic drugs: 2013 update. Ann Rheum Dis. Epub October 25, 2013.

23. Felson DT, Anderson JJ, Boers M, et al. American College of Rheumatology. Preliminary definition of improvement in rheumatoid arthritis. Arthritis Rheum. 1995;38(6):727-735.

24. van der Heijde DM, van't Hof MA, van Riel PL, et al. Judging disease activity in clinical practice in rheumatoid arthritis: first step in the development of a disease activity score. Ann Rheum Dis. 1990;49(11):916-920.

25. Nishimoto N, Miyasaka N, Yamamoto K, et al. Study of active controlled tocilizumab monotherapy for rheumatoid arthritis patients with an inadequate response to methotrexate (SATORI): significant reduction in disease activity and serum vascular endothelial growth factor by IL-6 receptor inhibition therapy. Mod Rheumatol. 2009;19(1):12-19.

26. Nishimoto N, Hashimoto J, Miyasaka N, et al. Study of active controlled monotherapy used for rheumatoid arthritis, an IL-6 inhibitor (SAMURAI): evidence of clinical and radiographic benefit from an $\mathrm{x}$ ray reader-blinded randomised controlled trial of tocilizumab. Ann Rheum Dis. 2007;66(9):1162-1167.

27. Kremer JM, Blanco R, Brzosko M, et al. Tocilizumab inhibits structural joint damage in rheumatoid arthritis patients with inadequate responses to methotrexate: results from the double-blind treatment phase of a randomized placebo-controlled trial of tocilizumab safety and prevention of structural joint damage at one year. Arthritis Rheum. 2011;63(3): 609-621.
28. Maini RN, Taylor PC, Szechinski J, et al; CHARISMA Study Group. Double-blind randomized controlled clinical trial of the interleukin-6 receptor antagonist, tocilizumab, in European patients with rheumatoid arthritis who had an incomplete response to methotrexate. Arthritis Rheum. 2006;54(9):2817-2829.

29. Smolen JS, Beaulieu A, Rubbert-Roth A, et al; OPTION Investigators. Effect of interleukin-6 receptor inhibition with tocilizumab in patients with rheumatoid arthritis (OPTION study): a double-blind, placebo-controlled, randomised trial. Lancet. 2008;371(9617): 987-997.

30. Genovese MC, McKay JD, Nasonov EL, et al. Interleukin-6 receptor inhibition with tocilizumab reduces disease activity in rheumatoid arthritis with inadequate response to disease-modifying antirheumatic drugs: the tocilizumab in combination with traditional disease-modifying antirheumatic drug therapy study. Arthritis Rheum. 2008;58(10): 2968-2980.

31. Yazici Y, Curtis JR, Ince A, et al. Early effects of tocilizumab in the treatment of moderate to severe active rheumatoid arthritis: a oneweek sub-study of a randomised controlled trial (Rapid Onset and Systemic Efficacy [ROSE] Study). Clin Exp Rheumatol. 2013;31(3): 358-364.

32. Emery P, Keystone E, Tony HP, et al. IL-6 receptor inhibition with tocilizumab improves treatment outcomes in patients with rheumatoid arthritis refractory to anti-tumour necrosis factor biologicals: results from a 24-week multicentre randomised placebo-controlled trial. Ann Rheum Dis. 2008;67(11):1516-1523.

33. Dougados M, Kissel K, Sheeran T, et al. Adding tocilizumab or switching to tocilizumab monotherapy in methotrexate inadequate responders: 24-week symptomatic and structural results of a 2-year randomised controlled strategy trial in rheumatoid arthritis (ACT-RAY). Ann Rheum Dis. 2013;72(1):43-50.

34. Weinblatt ME, Kremer J, Cush J, et al. Tocilizumab as monotherapy or in combination with nonbiologic disease-modifying antirheumatic drugs: twenty-four-week results of an open-label, clinical practice study. Arthritis Care Res (Hoboken). 2013;65(3):362-371.

35. Jones G, Sebba A, Gu J, et al. Comparison of tocilizumab monotherapy versus methotrexate monotherapy in patients with moderate to severe rheumatoid arthritis: the AMBITION study. Ann Rheum Dis. 2010;69(1):88-96.

36. Gabay C, Emery P, van Vollenhoven R, et al; ADACTA Study Investigators. Tocilizumab monotherapy versus adalimumab monotherapy for treatment of rheumatoid arthritis (ADACTA): a randomised, double-blind, controlled phase 4 trial. Lancet. 2013;381(9877): 1541-1550.

37. Ogata A, Tanimura K, Sugimoto T, et al. A phase 3 study of the efficacy and safety of subcutaneous versus intravenous tocilizumab monotherapy in patients with rheumatoid arthritis (MUSASHI). Arthritis Care Res (Hoboken). Epub August 27, 2013.

38. Burmester GR, Rubbert-Roth A, Cantagrel A, et al. A randomised, double-blind, parallel-group study of the safety and efficacy of subcutaneous tocilizumab versus intravenous tocilizumab in combination with traditional disease-modifying antirheumatic drugs in patients with moderate to severe rheumatoid arthritis (SUMMACTA study). Ann Rheum Dis. 2014;73(1):69-74.

39. Singh JA, Beg S, Lopez-Olivo MA. Tocilizumab for rheumatoid arthritis: a Cochrane systematic review. J Rheumatol. 2011;38(1):10-20.

40. Levi M, Grange S, Frey N. Exposure-response relationship of tocilizumab, an anti-IL-6 receptor monoclonal antibody, in a large population of patients with rheumatoid arthritis. J Clin Pharmacol. 2013;53(2): 151-159.

41. Singh JA, Wells GA, Christensen R, et al. Adverse effects of biologics: a network meta-analysis and Cochrane overview. Cochrane Database Syst Rev. 2011;2:CD008794.

42. Lang VR, Englbrecht M, Rech J, et al. Risk of infections in rheumatoid arthritis patients treated with tocilizumab. Rheumatology (Oxford). 2012;51(5):852-857. 
43. Schiff MH, Kremer JM, Jahreis A, Vernon E, Isaacs JD, van Vollenhoven RF. Integrated safety in tocilizumab clinical trials. Arthritis Res Ther. 2011;13(5):R141.

44. Koike T, Harigai M, Inokuma S, et al. Postmarketing surveillance of tocilizumab for rheumatoid arthritis in Japan: interim analysis of 3881 patients. Ann Rheum Dis. 2011;70(12):2148-2151.

45. Actemra ${ }^{\circledR}$ (tocilizumab) [package insert]. South San Francisco: Genentech, Inc.; 2010.

46. Strang AC, Bisoendial RJ, Kootte RS, et al. Pro-atherogenic lipid changes and decreased hepatic LDL receptor expression by tocilizumab in rheumatoid arthritis. Atherosclerosis. 2013;229(1): 174-181.

47. Genovese MC, McKay JD, Nasonov EL, et al. Interleukin-6 receptor inhibition with tocilizumab reduces disease activity in rheumatoid arthritis with inadequate response to disease-modifying antirheumatic drugs: the tocilizumab in combination with traditional disease-modifying antirheumatic drug therapy study. Arthritis Rheum. 2008;58(10): 2968-2980.

48. Smolen JS, Schoels MM, Nishimoto N, et al. Consensus statement on blocking the effects of interleukin- 6 and in particular by interleukin- 6 receptor inhibition in rheumatoid arthritis and other inflammatory conditions. Ann Rheum Dis. 2013;72(4):482-492.

49. Dursunoğlu D, Evrengül H, Polat B, et al. Lp(a) lipoprotein and lipids in patients with rheumatoid arthritis: serum levels and relationship to inflammation. Rheumatol Int. 2005;25(4):241-245.

50. Kume K, Amano K, Yamada S, Hatta K, Ohta H, Kuwaba N. Tocilizumab monotherapy reduces arterial stiffness as effectively as etanercept or adalimumab monotherapy in rheumatoid arthritis: an open-label randomized controlled trial. J Rheumatol. 2011;38(10): 2169-2171.

51. Schiff MH, Kremer JM, Jahreis A, Vernon E, Isaacs JD, van Vollenhoven RF. Integrated safety in tocilizumab clinical trials. Arthritis Res Ther. 2011;13(5):R141.

52. Gout T, Ostör AJ, Nisar MK. Lower gastrointestinal perforation in rheumatoid arthritis patients treated with conventional DMARDs or tocilizumab: a systematic literature review. Clin Rheumatol. 2011;30(11):1471-1474.

53. Genovese MC, Rubbert-Roth A, Smolen JS, et al. Longterm safety and efficacy of tocilizumab in patients with rheumatoid arthritis: a cumulative analysis of up to 4.6 years of exposure. J Rheumatol. 2013;40(6):768-780.

54. Bykerk VP, Ostör AJ, Alvaro-Gracia J, et al. Tocilizumab in patients with active rheumatoid arthritis and inadequate responses to DMARDs and/or TNF inhibitors: a large, open-label study close to clinical practice. Ann Rheum Dis. 2012;71(12):1950-1954.

55. Bombardieri S, Ruiz AA, Fardellone P, et al; Research in Active Rheumatoid Arthritis (ReAct) Study Group. Effectiveness of adalimumab for rheumatoid arthritis in patients with a history of TNF-antagonist therapy in clinical practice. Rheumatology (Oxford). 2007;46(7):1191-1199.

56. Woodrick RS, Ruderman EM. Interleukin 6 inhibition - RA and beyond. Bull NYU Hosp Jt Dis. 2011;69(3):225-229.

57. Yokota S, Imagawa T, Mori M, et al. Efficacy and safety of tocilizumab in patients with systemic-onset juvenile idiopathic arthritis: a randomised, double-blind, placebo-controlled, withdrawal phase III trial. Lancet. 2008;371(9617):998-1006.

58. Chen DY, Lan JL, Lin FJ, Hsieh TY. Proinflammatory cytokine profiles in sera and pathological tissues of patients with active untreated adult onset Still's disease. J Rheumatol. 2004;31(11):2189-2198.

59. Puéchal X, DeBandt M, Berthelot JM, et al; Club Rhumatismes Et Inflammation. Tocilizumab in refractory adult Still's disease. Arthritis Care Res (Hoboken). 2011;63(1):155-159.

60. Nakahara H, Mima T, Yoshio-Hoshino N, Matsushita M, Hashimoto J, Nishimoto N. A case report of a patient with refractory adult-onset Still's disease who was successfully treated with tocilizumab over 6 years. Mod Rheumatol. 2009;19(1):69-72.
61. Linker-Israeli M, Deans RJ, Wallace DJ, Prehn J, Ozeri-Chen T, Klinenberg JR. Elevated levels of endogenous IL-6 in systemic lupus erythematosus. A putative role in pathogenesis. J Immunol. 1991;147(1):117-123.

62. Illei GG, Shirota Y, Yarboro CH, et al. Tocilizumab in systemic lupus erythematosus: data on safety, preliminary efficacy, and impact on circulating plasma cells from an open-label phase I dosage-escalation study. Arthritis Rheum. 2010;62(2):542-552.

63. Park MC, Lee SW, Park YB, Lee SK. Serum cytokine profiles and their correlations with disease activity in Takayasu's arteritis. Rheumatology (Oxford). 2006;45(5):545-548.

64. Tombetti E, Franchini S, Papa M, Sabbadini MG, Baldissera E. Treatment of refractory Takayasu arteritis with tocilizumab: 7 Italian patients from a single referral center. $J$ Rheumatol. 2013;40(12): 2047-2051

65. Abisror N, Mekinian A, Lavigne C, Vandenhende MA, Soussan M, Fain O; Club Rhumatismes et Inflammation, and SNFMI. Tocilizumab in refractory Takayasu arteritis: a case series and updated literature review. Autoimmun Rev. 2013;12(12):1143-1149.

66. Ishioka S, Saito T, Hiyama K, et al. Increased expression of tumor necrosis factor-alpha, interleukin-6, platelet-derived growth factor-B and granulocyte-macrophage colony-stimulating factor mRNA in cells of bronchoalveolar lavage fluids from patients with sarcoidosis. Sarcoidosis Vasc Diffuse Lung Dis. 1996;13(2):139-145.

67. Balamugesh T, Behera D, Bhatnagar A, Majumdar S. Inflammatory cytokine levels in induced sputum and bronchoalveolar lavage fluid in pulmonary sarcoidosis. Indian J Chest Dis Allied Sci. 2006;48(3): 177-181.

68. Nutz A, Pernet C, Combe B, Cohen JD. Sarcoidosis induced by tocilizumab: a paradoxical event? J Rheumatol. 2013;40(10): 1773-1774.

69. Larsson PT, Hallerstam S, Rosfors S, Wallén NH. Circulating markers of inflammation are related to carotid artery atherosclerosis. Int Angiol. 2005;24(1):43-51

70. Kume K, Amano K, Yamada S, Hatta K, Ohta H, Kuwaba N. Tocilizumab monotherapy reduces arterial stiffness as effectively as etanercept or adalimumab monotherapy in rheumatoid arthritis: an open-label randomized controlled trial. J Rheumatol. 2011;38(10): 2169-2171.

71. Conway DS, Buggins P, Hughes E, Lip GY. Prognostic significance of raised plasma levels of interleukin- 6 and $\mathrm{C}$-reactive protein in atrial fibrillation. Am Heart J. 2004;148(3):462-466.

72. Ohtori S, Miyagi M, Eguchi Y, et al. Efficacy of epidural administration of anti-interleukin-6 receptor antibody onto spinal nerve for treatment of sciatica. Eur Spine J. 2012;21(10):2079-2084.

73. Lin JT, Wang JY, Chen MK, et al. Colon cancer mesenchymal stem cells modulate the tumorigenicity of colon cancer through interleukin 6 . Exp Cell Res. 2013;319(14):2216-2229.

74. Okitsu K, Kanda T, Imazeki F, et al. Involvement of interleukin-6 and androgen receptor signaling in pancreatic cancer. Genes Cancer. 2010;1(8):859-867.

75. Ohishi W, Cologne JB, Fujiwara S, et al. Serum interleukin-6 associated with hepatocellular carcinoma risk: a nested case-control study. Int $J$ Cancer. 2014;134(1):154-163.

76. Shinriki S, Jono H, Ota K, et al. Humanized anti-interleukin-6 receptor antibody suppresses tumor angiogenesis and in vivo growth of human oral squamous cell carcinoma. Clin Cancer Res. 2009;15(17): 5426-5434.

77. Jordan SC, Kahwaji J, Toyoda M, Vo A. B-cell immunotherapeutics: emerging roles in solid organ transplantation. Curr Opin Organ Transplant. 2011;16(4):416-424.

78. Cedars-Sinai Medical Center. A safety study of tocilizumab to improve transplant rates in highly sensitized patients awaiting kidney transplantation. Available from: http://clinicaltrials.gov/show/ NCT01594424. NLM identifier: NCT01594424. Accessed November $1,2013$. 
79. Weill Medical College of Cornell University. Phase II study of tocilizumab for patients with glucocorticoid-refractory acute GVHD after allogeneic hematopoetic stem cell transplant (HSCT). Available from: http://clinicaltrials.gov/ct2/show/NCT01757197?ter $\mathrm{m}=\mathrm{NCT} 01757197 \&$ rank=1. NLM identifier: NCT01757197. Accessed November 1, 2013.

80. Sanofi. To Evaluate The Safety of SAR153191 (REGN88) and Tocilizumab Added to Other RA Drugs in Patients With RA Who Are Not Responding to or Intolerant of Anti-TNF Therapy (SARIL-RA-ASCERTAIN). Available from http://clinicaltrials.gov/show/NCT01768572. NLM identifier: NCT01768572. Accessed November 1, 2013.

81. Janssen Research \& Development. A Study of CNTO 136 (Sirukumab), a Human Anti-IL-6 Monoclonal Antibody, Administered Subcutaneously, in Patients With Active Rheumatoid Arthritis Despite Anti-TNFAlpha Therapy (SIRROUND). Available from http://clinicaltrials.gov/ ct2/show/NCT01606761?term=sirukumab\&rank=2. NLM identifier: NCT01606761. Accessed November 1, 2013.
82. Sanofi. Evaluation of SAR153191(REGN88)(Sarilumab) on Top of Methotrexate in Rheumatoid Arthritis Patients (RA-MOBILITY). Available from: http://www.clinicaltrials.gov/ct2/show/NCT01061736. NLM identifier: NCT01061736. Accessed November 1, 2013.

83. Hsu B, Sheng S, Smolen J, et al. Results from a 2-part, proof of concept, dose ranging, randomized, double-blind, placebo-controlled, phase 2 study of sirukumab, a human anti-interleukin-6 monoclonal antibody, in patients with active rheumatoid arthritis despite methotrexate therapy. Annals Rheumatic Diseases, 2012;71(Suppl 3):188.

\section{Publish your work in this journal}

Drug Design, Development and Therapy is an international, peerreviewed open-access journal that spans the spectrum of drug design and development through to clinical applications. Clinical outcomes, patient safety, and programs for the development and effective, safe, and sustained use of medicines are a feature of the journal, which has also been accepted for indexing on PubMed Central. The manuscript management system is completely online and includes a very quick and fair peer-review system, which is all easy to use. Visit http://www.dovepress.com/testimonials.php to read real quotes from published authors.

Submit your manuscript here: http://www.dovepress.com/drug-design-development-and-therapy-journal 